\title{
Diet and mortality rates in Sub-Saharan Africa: Stages in the nutrition transition
}

\author{
Zulfa Abrahams ${ }^{*}$, Zandile Mchiza and Nelia P Steyn
}

\begin{abstract}
Background: During the last century we have seen wide-reaching changes in diet, nutritional status and life expectancy. The change in diet and physical activity patterns has become known as the nutrition transition. At any given time, a country or region within a country may be at different stages within this transition. This paper examines a range of nutrition-related indicators for countries in Sub-Saharan Africa (SSA) and attempts to develop a typical model of a country in transition.

Methods: Based on the availability of data, 40 countries in SSA were selected for analysis. Data were obtained from the World Health Organisation, Demographic and Health Surveys and the Food and Agriculture Organisation of the United Nations. Multiple linear regression analysis (MLRA) was used to explore the determinants of infant mortality. A six point score was developed to identify each country's stage in the nutrition transition.

Results: MLRA showed that underweight-for-age, protein and the percentage of exclusively breastfed infants were associated with the infant mortality rate (IMR). The majority of countries $(n=26)$ used in the analysis had nutrition transition scores of zero and one. Most of them had a high prevalence of infant mortality, children that were stunted or underweight-for-age, small percentages of women that were overweight and obese, and low intakes of energy, protein, and fat. Countries with the highest scores include South Africa, Ghana, Gabon, Cape Verde and Senegal which had relatively low IMRs, high levels of obesity/overweight, and low levels of underweight in women, as well as high intakes of energy and fat. These countries display classic signs of a population well established in the nutrition-related non-communicable disease phase of the nutrition transition.

Conclusions: Countries in SSA are clearly undergoing a nutrition transition. More than half of them are still in the early stage, while a few have reached a point where changes in dietary patterns are affecting health outcomes in a large portion of the population. Those in the early stage of the transition are especially important, since primordial prevention can still be introduced.
\end{abstract}

\section{Background}

Developed (high-income) and developing (low-to-medium income) countries differ significantly in causes of death. The leading causes of mortality in developed countries are non-communicable diseases (NCD) such as type 2 diabetes, cardiovascular diseases and cancer which account for approximately two-thirds of all deaths [1]. However, these diseases account for only one-third of deaths in the developing world, where infectious diseases and malnutrition, particularly in infants, account for up to 43 percent of deaths [1]. Furthermore, NCDs that used to be associated with old age in high-income countries are becoming

\footnotetext{
* Correspondence: zabrahams@hsrc.ac.za

Centre for the Study of Social and Environmental Determinants of Nutrition, Human Sciences Research Council (HSRC), Cape Town, South Africa
}

more prevalent in the developing world following the rapid increase in industrialization, urbanization, economic development and globalization [1].

During the last century we have seen wide-reaching changes in diet, nutritional status, disease patterns and life expectancy. These changes are thought to occur as three separate transition processes. The demographic transition refers to a change from a period of high fertility and mortality to one of low fertility and mortality which occurs as a result of an increase in income, education and employment [2], while the epidemiological transition refers to a change from a period of high prevalence of infectious disease associated with poor sanitation, famine and malnutrition, to a period of high prevalence of chronic and degenerative diseases [3,4].

\section{() Biomed Central}


A period of transition thought to precede or occur simultaneously with the demographic and epidemiological transitions is the nutrition transition, resulting from a change in diet and physical activity patterns [5]. Popkin refers to this transition occurring in five stages.

During the first stage (hunter-gatherer), diets were high in carbohydrates and fibre and low in fat (especially saturated fat). Activity levels were high, and obesity levels low. The second stage (famine) refers to a period where food was scarce and dietary diversity low. While the type of physical activity done may have changed, the activity levels remained much the same. These changes are related to a shift toward settlements and cultivation, first of crops and later also livestock and poultry. During the third stage (receding famine), the amount of carbohydrates in the diet decreased, and fruit, vegetables and protein consumption increased. Physical activity levels started to decrease. This is the development of more technically advanced and productive agriculture. The fourth stage (nutrition-related non-communicable disease) is characterized by a diet high in fat, refined carbohydrates, sugar and cholesterol and low in fibre. Physical activity levels are low, and obesity prevalence high. The final stage (behavioural change) occurs due to a desire to prolong health and delay or prevent degenerative diseases. The consumption of complex carbohydrates, fruit and vegetables increases, while the consumption of fat, processed foods, meat and dairy products are reduced [4-6]. At any given time, a country or region within a country may be at a different stage within this transition.

While most high-income, developed countries seem to be in the final stage of the nutrition transition [5]; developing countries [6] have not been immune to this transition. Poor countries are plagued by the same risk factors (diets high in sugar, fat and alcohol, obesity, tobacco smoking and lack of physical activity) as their rich counterparts [7]. Furthermore, rural and urban areas within the same country may be at different stages of the transition.

Urban residents have access to a wider range of food products, many of which are high in fat and sugar. In addition, an increasing number of women are working, leaving less time for growing and producing food, shopping for ingredients, and preparing the often energy-intensive staples of traditional diets. Families therefore rely on processed foods, resulting in the development of obesity [1]. This is further exacerbated by the sedentary activities associated with urban jobs and the increase in the availability of televisions and computers.

Sub-Saharan Africa (SSA), made up of low- and middleincome countries, is undergoing a health transition causing these countries to experience a double burden of disease. The nutrition transition appears to be accelerating in SSA from the receding famine stage to the nutritionrelated non-communicable disease stage. As a result, an increasing number of households are experiencing the dual burden of underweight and obesity occurring simultaneously $[8,9]$. At the same time high rates of NCDs, like diabetes, cardiovascular disease and cancer are occurring together with infectious diseases such as HIV/AIDS, tuberculosis and malaria [10].

Community studies from South Africa [11,12] have found that underweight and stunting coexist with overweight and obesity. In a study by Garrett and Ruel [13], using demographic and health survey (DHS) data from several developing countries, the relationship between stunted children and overweight and obese mothers was confirmed. In SSA, the percentage of stunted children with overweight mothers ranged from $0.6 \%$ in Mozambique to $8.2 \%$ in Namibia.

Countries in SSA are currently experiencing changes associated with the advancing nutrition transition, while at the same time struggling to eradicate the high prevalence of infant and child mortality prevalent in developing countries. This paper examines the role of a number of indicators associated with the advancing nutrition transition, as well as the prevalence of infant mortality and the factors impacting on its prevalence in SSA.

In this paper we hypothesise that countries in the advanced stage of the transition have adopted 'western' diets and are now plagued by high levels of overweight and obesity, and high levels of NCD mortality. They generally have fewer people living in poverty. Moreover, their levels of underweight-for-age, stunting and IMR may have decreased. Based on this hypothesis, a scoring system was developed and used to define a typical model of a country in transition.

\section{Methods}

The current study is a secondary analysis of existing data available on IMR and mortality due to chronic NCD (NCD MR) in SSA, as well as their determinants. Forty countries in SSA were selected based on the availability of data from primary sources World Health Organisation (WHO) [14], Demographic and Health Surveys (DHS) [15] and the Food and Agriculture Organisation of the United Nations (FAO) [16]. Nutrition-related indicators which may have influenced the nutrition transition, as well as indicators associated with infant and child mortality were selected from the data available. A list of the key indicators and their definitions is shown in Table 1.

The most recent data (2000-2008) from the WHO Global Health Observatory Database [14] were used to obtain information on each country's IMR, the percentage stunting, underweight-for-age, low birth weight and exclusively breastfed infants, NCD mortality, prevalence of HIV among adults, and the percentage of the population living on less than one dollar per day (PPP). Zere and McIntyre [17] provided information on the prevalence of stunting 
Table 1 Definition of key indicators

\begin{tabular}{|c|c|}
\hline Indicators & Definition \\
\hline Infant Mortality Rate (IMR) & Probability of dying between birth and age 1 per 1000 live births \\
\hline Stunting & $\begin{array}{l}\text { Children }<5 \text { years that are stunted for age }(\%) \\
\text { [Height-for-age Z-score } \leq-2 \text { SD] }\end{array}$ \\
\hline Underweight-for-age & Children $<5$ years that are underweight for age (\%) [Underweight-for-age Z-score $\leq-2 \mathrm{SD}$ ] \\
\hline Low Birth Weight & Low-birth-weight newborns (\%) \\
\hline Exclusively Breastfed & Infants exclusively breastfed for the first 6 months of life (\%) \\
\hline $\begin{array}{l}\text { Non-communicable Disease } \\
\text { Mortality Rate (NCD MR) }\end{array}$ & Age-standardized mortality rate by cause (per 100000 population)-due to NCD \\
\hline Underweight & Adult women with a BMI < $18.5(\%)$ \\
\hline Normal Weight & Adult women with a BMl of 18.5-24.9 (\%) \\
\hline Overweight/obese & Adult women with a $\mathrm{BMI}>25(\%)$ \\
\hline PPP & Population living on $<\$ 1$ a day $(\%)$ \\
\hline HIV prevalence & Prevalence of HIV among adults aged 15-49 (\%) \\
\hline Dietary energy supply (DES) & Dietary energy supply (kcal/capita/day) \\
\hline Protein & Protein supply quantity (g/capita/day) \\
\hline Energy from protein & Energy obtained from protein (\%) \\
\hline Fat & Fat supply quantity (g/capita/day) \\
\hline Energy from fat & Energy obtained from fat (\%) \\
\hline Carbohydrates & Carbohydrate supply quantity (g/capita/day) \\
\hline Energy from carbohydrates & Energy obtained from carbohydrates (\%) \\
\hline
\end{tabular}

and underweight in South African children younger than five years.

Country reports from the most recent DHS [15] were used to obtain information on mean Body Mass Index (BMI) of adult women. BMI was stratified into the percentage of women who were underweight (BMI < 18.5), were within the normal weight range $(\mathrm{BMI}=18.5-24.9)$, or were overweight and obese (BMI > 25).

The 2008 food balance sheets from FAO [16] were used to gather information on dietary energy supply (DES), protein and fat per capita available in each country. The information obtained was used to generate values for carbohydrate supply. In addition, values for the percentage of energy from protein [(grams of protein $\times 4$ calories $) \div$ (calories of energy $\times 100)]$, fat [(grams of fat $\times 9$ calories $) \div$ (calories of energy $\times 100)$ ] and carbohydrates [(grams of carbohydrates $\times 4$ calories $) \div($ calories of energy $\times 100)$ ] were calculated.

The IMR was selected as an independent variable. Pearson and Spearman correlations were then used to identify associations between IMR and various predictor variables. Multiple linear regression analysis was used to explore the determinants of IMR using possible predictor variables. All variables that may have an impact on IMR were included in the analysis, irrespective of results obtained from Pearson and Spearman correlations. The predictor variables used were stunting, underweight-for-age, PPP, HIV prevalence, energy, protein, fat, carbohydrates, energy from protein, energy from fat and energy from carbohydrates.

A scoring system was developed to help identify the stage of nutrition transition in each country. Indicators included in the scoring system were based on trends associated with the advancing nutrition transition. The advanced stage of the transition is associated with diets high in energy and fat, growing levels of overweight/ obesity, decreasing levels of infant mortality and stunting, high levels of NCD mortality [7], and possibly a smaller percentage of the population living on less than $\$ 1$ per day.

A score of one was allocated to each country whose score for the following indicators were in the top quartile of the range: energy, percentage of energy from fat and overweight/obesity. Countries whose score for the following indicators were in the bottom quartile of the range were also allocated a score of one: PPP, IMR and stunting. All indicators that did not receive a score of one automatically received a score of zero. The highest possible score was six and the lowest was zero. A score of six is representative of a country in the last phase of the nutrition transition while zero indicates a country in very early stages of transition. A score close to zero would encapsulate the famine stage and would typically be a country with a low per capita energy intake, high IMR, high prevalence of stunting and low prevalence of obesity. A score close to six, on the other hand, would reflect a high energy intake, low IMR and stunting and a high prevalence of obesity.

\section{Results}

From a total of 48 countries in SSA, sufficient recent data were available for 40 countries. Those excluded were: Botswana, Djibouti, Equatorial Guinea, Mauritania, 
Mauritius, Seychelles, Somalia and Sudan. Table 1 defines the key indicators used. Tables 2 and 3 show the key indicators for 40 countries in SSA. A number of countries still have IMRs above 100 with the highest being Angola (130), Democratic Republic of Congo (DRC) (126), Chad (124) and Sierra Leone (123). Some countries still show a prevalence of stunting in more than $50 \%$ of children (Angola, Burundi, Ethiopia, Madagascar, Malawi, Niger and Rwanda). Another important nutrition indicator-exclusive breastfeeding was lower than $10 \%$ in some countries (Burkina Faso, Chad, Cote d'Ivoire, South Africa (RSA) and Gabon). In Angola, Niger and Sierra Leone the NCD MR was above 1000 deaths per 100 000. Countries in which more than three quarters of the population live on less than 1 dollar per day include Burundi, Liberia, Rwanda and Tanzania.

In terms of diet composition, results show that the average DES was $2279 \pm 334 \mathrm{kcal} / \mathrm{capita} /$ day. Three countries had a DES less than 1800 (Burundi, DRC and Eritrea) and another 5 less than 2000 (Angola, Central African Republic (CAR), Comoros, Ethiopia and Zambia). Figures 1a, b and 1c show that the diet in SSA consists primarily of carbohydrates (> 55\% of the overall DES) with protein supplying less than $15 \%$ of the overall DES. The average available protein intake was $56.0 \pm 12.6 \mathrm{~g} /$ capita/day, supplying an average of $9.8 \pm 1.6 \%$ of the overall DES. Countries with the lowest protein intakes (less than $45 \mathrm{~g} /$ capita/day) were Angola, Guinea-Bissau, Comoros, DRC, Liberia, and Mozambique. The average available fat intake was $48.6 \pm 16 \mathrm{~g} /$ capita/day, which supplied an average of $18.9 \pm 5 \%$ of the overall DES. Five countries had an extremely low fat intake of less than 30 g/capita/day: Burundi, DRC, Eritrea, Ethiopia, and Rwanda.

The results of correlations between independent variable IMR and several predictor variables are shown in Table 4. Correlations between IMR and predictor variables that were statistically significant include stunting $(\mathrm{p}=0.01)$, underweight-for-age $(\mathrm{p}=0.02), \operatorname{PPP}(\mathrm{p}=$ $0.02)$, energy $(p=0.04)$, protein $(p=0.01)$ and the percentage of energy from protein (0.04).

Multiple logistic regression analysis was used to explore the determinants of IMR. All variables used in the univariate analysis (Table 3) were included, irrespective of whether they were significantly associated with the IMR. Table 5 shows that underweight-for-age $(\mathrm{p}=0.02)$, protein $(\mathrm{p}=0.001)$ and the percentage of exclusively breastfed infants $(p=0.003)$ are associated with the IMR. As the percentage of children that are underweight-for-age increases, the IMR increases. Conversely, an increase in the protein supply and number of exclusively breastfed infants results in a decrease in the IMR. Stunting, HIV prevalence, PPP, total energy, and energy from protein were no longer significant, whereas exclusive breastfeeding became significant. The determinants of NCD MR were explored and excluded since the NCD MR are estimates based on assumptions and extrapolations due to the lack of reliable mortality and morbidity data from SSA [18].

Figure 2 shows the relationship between stunted children and overweight/obese women. Findings show that, to differing degrees, all countries have stunted children and overweight/obese woman. The percentages of stunted children coupled with overweight/obese women were especially high in Lesotho, Swaziland, Cameroon and Sao Tome and Principe.

A scoring system was developed to assess each country's stage in the nutrition transition (Table 6). Countries with the highest scores include RSA which scored a six, Ghana, Gabon and Cape Verde which scored five, and Senegal which scored four. These countries had relatively low IMR (24-57 deaths per 1000 live births), relatively high levels of obesity/overweight (> 29\%), and low levels of underweight (6-9\%) in women, as well as high intakes of energy (DES > $2500 \mathrm{kcal} /$ capita/day) and fat (> $50 \mathrm{~g} / \mathrm{capita} /$ day) and average NCD MR (591-867 deaths per 100 000). Countries having a zero score include Angola, Burundi, Chad, Comoros, Congo Brazzaville, DRC, Ethiopia, Madagascar, Malawi, Mozambique, Niger, Rwanda, Tanzania, Uganda and Zambia. They are characterized by many in the population living on less than 1 dollar per day (39-81\%), a low DES (1600-2500cal/capita/day), low energy intake from fat (7-21\%), a low prevalence of obesity (4-22\%), and a high prevalence of stunting (31-63\%). Although they do not all lie in the highest quartile for IMR it still remains high being between 65 and 124 in these countries.

\section{Discussion}

It has long been accepted that the health status of a population is dependent on many inter-connected factors. Environmental, socio-economic and political influences are all associated with attaining health. This study has looked at the impact of nutrition (DES, protein, carbohydrate and fat intakes) on IMR and undernutrition in children and in overnutrition in adults

One of the most important findings of this SSA study is the significant relationship between IMR with exclusive breastfeeding and available protein intake shown in the multiple regression analysis. Stunting, DES and PPP were not significant predictors of IMR, despite them being significant in the univariate analysis. It appears that the strong relationship between IMR and these variables were by chance, and once confounding was controlled for, the significant associations disappeared.

Indeed, the regression analysis in the current study showed exclusive breastfeeding to be significantly associated with IMR, even though it was insignificant in the univariate analysis. It is disheartening to know that only a small prevalence $(33.6 \pm 20 \%)$ of mothers in SSA countries 
Table 2 Key Indicators from $\mathbf{4 0}$ countries in Sub-Saharan Africa

\begin{tabular}{|c|c|c|c|c|c|c|c|c|c|}
\hline Country & $\begin{array}{c}\text { Infant } \\
\text { Mortality } \\
\text { Rate }\end{array}$ & $\begin{array}{l}\text { Stunting } \\
(\%)\end{array}$ & $\begin{array}{l}\text { Underweight- } \\
\text { for-Age (\%) }\end{array}$ & $\begin{array}{l}\text { Low birth } \\
\text { weight (\%) }\end{array}$ & $\begin{array}{c}\text { Exclusively } \\
\text { Breastfed (\%) }\end{array}$ & $\begin{array}{c}\text { NCD } \\
\text { Mortality } \\
\text { Rate }\end{array}$ & $\begin{array}{c}\text { Under } \\
\text { weight } \\
(\%)\end{array}$ & $\begin{array}{c}\text { Normal } \\
\text { Weight } \\
(\%)\end{array}$ & $\begin{array}{c}\text { Overweight/ } \\
\text { Obese (\%) }\end{array}$ \\
\hline Angola* & 130 & 50.8 & 27.5 & 12 & 11.1 & 1071 & $\mathrm{n} / \mathrm{a}$ & $\mathrm{n} / \mathrm{a}$ & $\mathrm{n} / \mathrm{a}$ \\
\hline Benin & 76 & 44.7 & 20.2 & 15 & 43.1 & 835 & 9.2 & 71.8 & 19 \\
\hline Burkina Faso & 92 & 44.5 & 37.4 & 16 & 6.8 & 924 & 20.8 & 69.9 & 9.3 \\
\hline Burundi* & 102 & 63.1 & 38.9 & 11 & 44.7 & 919 & $\mathrm{n} / \mathrm{a}$ & $\mathrm{n} / \mathrm{a}$ & $\mathrm{n} / \mathrm{a}$ \\
\hline Cameroon & 82 & 36.4 & 16.6 & 11 & 21.2 & 840 & 6.7 & 64.6 & 49.3 \\
\hline Cape Verde* & 24 & 21.4 & 11.8 & 6 & 59.6 & 591 & $\mathrm{n} / \mathrm{a}$ & $\mathrm{n} / \mathrm{a}$ & $\mathrm{n} / \mathrm{a}$ \\
\hline $\begin{array}{l}\text { Central African } \\
\text { Republic* (CAR) }\end{array}$ & 115 & 44.6 & 21.8 & 13 & 23.1 & 868 & $\mathrm{n} / \mathrm{a}$ & $\mathrm{n} / \mathrm{a}$ & $\mathrm{n} / \mathrm{a}$ \\
\hline Chad & 124 & 44.8 & 33.9 & 22 & 2.1 & 910 & 20.3 & 72 & 9.6 \\
\hline Comoros & 75 & 46.9 & 25.0 & 25 & 21.3 & 713 & 9.8 & 67.5 & 18.4 \\
\hline Congo Brazzaville* & 80 & 31.2 & 11.8 & 13 & 19.1 & 716 & $\mathrm{n} / \mathrm{a}$ & $\mathrm{n} / \mathrm{a}$ & $\mathrm{n} / \mathrm{a}$ \\
\hline Cote d'Ivoire* & 81 & 40.1 & 16.7 & 17 & 4.3 & 946 & $\mathrm{n} / \mathrm{a}$ & $\mathrm{n} / \mathrm{a}$ & $\mathrm{n} / \mathrm{a}$ \\
\hline $\begin{array}{c}\text { Democratic Republic } \\
\text { of Congo (DRC) }\end{array}$ & 126 & 45.8 & 28.2 & 12 & 36.1 & 921 & 18.4 & 71.3 & 11.3 \\
\hline Eritrea* & 41 & 43.7 & 34.5 & 14 & 52 & 686 & 37.3 & 53.8 & 8.9 \\
\hline Ethiopia & 69 & 50.7 & 34.6 & 20 & 49 & 817 & 25.6 & 69.1 & 4.4 \\
\hline Gabon & 57 & 26.3 & 8.8 & 14 & 5.2 & 716 & 6.6 & 64 & 29.5 \\
\hline Gambia* & 80 & 27.6 & 15.8 & 20 & 40.8 & 830 & $\mathrm{n} / \mathrm{a}$ & $\mathrm{n} / \mathrm{a}$ & $n / a$ \\
\hline Ghana & 51 & 28.6 & 14.3 & 9 & 62.8 & 699 & 8.6 & 61.4 & 30 \\
\hline Guinea & 90 & 40.0 & 20.8 & 12 & 48.1 & 844 & 13.2 & 72.5 & 14.3 \\
\hline Guinea-Bissau* & 117 & 28.1 & 17.2 & 24 & 27.9 & 925 & $\mathrm{n} / \mathrm{a}$ & $\mathrm{n} / \mathrm{a}$ & $\mathrm{n} / \mathrm{a}$ \\
\hline Kenya & 81 & 35.8 & 16.5 & 10 & $\mathrm{n} / \mathrm{a}$ & 729 & 12.3 & 62.6 & 25.1 \\
\hline Lesotho & 63 & 45.2 & 16.6 & 13 & 36.4 & 581 & 5.7 & 52 & 42.3 \\
\hline Liberia & 100 & 39.4 & 20.4 & 14 & 29.1 & 931 & 10 & 69.4 & 20.5 \\
\hline Madagascar & 68 & 52.8 & 36.8 & 17 & n/a & 799 & 26.7 & 67 & 6.3 \\
\hline Malawi & 65 & 53.2 & 15.5 & 13 & 56.7 & 796 & 9.2 & 77.1 & 13.6 \\
\hline Mali & 102 & 38.5 & 27.9 & 19 & 37.8 & 967 & 13.5 & 68.9 & 17.6 \\
\hline Mozambique* & 90 & 47 & 21.2 & 15 & 30 & 777 & $\mathrm{n} / \mathrm{a}$ & $\mathrm{n} / \mathrm{a}$ & $n / a$ \\
\hline Namibia* & 31 & 29.6 & 17.5 & 16 & 23.9 & 513 & 15.9 & 56 & 28.1 \\
\hline Niger & 79 & 54.8 & 39.9 & 27 & $\mathrm{n} / \mathrm{a}$ & 1030 & 19.2 & 67.9 & 22.7 \\
\hline Nigeria & 96 & 41.0 & 26.7 & 14 & 13.1 & 909 & 12.2 & 65.7 & 22.1 \\
\hline Rwanda & 72 & 51.7 & 18.0 & 6 & 88.4 & 878 & 9.8 & 78.7 & 11.5 \\
\hline $\begin{array}{l}\text { Sao Tome and } \\
\text { Principe* }\end{array}$ & 64 & 35.2 & 10.1 & 8 & $\mathrm{n} / \mathrm{a}$ & 788 & 7.7 & 58.7 & 33.7 \\
\hline Senegal* & 57 & 20.1 & 14.5 & 19 & 34.1 & 852 & $\mathrm{n} / \mathrm{a}$ & $\mathrm{n} / \mathrm{a}$ & $\mathrm{n} / \mathrm{a}$ \\
\hline Sierra Leone & 123 & 37.4 & 21.3 & 24 & 11.2 & 1033 & 11.2 & 59.1 & 29.7 \\
\hline South Africa (RSA) & 48 & $24.5^{16}$ & $17.0^{16}$ & 15 & 7.2 & 867 & 6.2 & 38.9 & 54.9 \\
\hline Swaziland & 59 & 29.5 & 6.1 & 9 & 32.3 & 707 & 3.2 & 46.2 & 50.6 \\
\hline Tanzania & 67 & 44.4 & 16.7 & 14 & 60.1 & 851 & 10.4 & 71.8 & 17.7 \\
\hline Togo & 64 & 26.9 & 20.5 & 10 & 41.3 & 818 & 10.9 & 77.8 & 11.4 \\
\hline Uganda & 84 & 38.7 & 16.4 & 12 & 48 & 786 & 12.1 & 71.3 & 16.5 \\
\hline Zambia & 92 & 45.8 & 14.9 & 11 & 60.7 & 833 & 9.6 & 71.2 & 19.2 \\
\hline Zimbabwe* & 62 & 35.8 & 14.0 & 11 & 22.2 & 816 & 9.2 & 65.8 & 25 \\
\hline Mean & 79.5 & 39.7 & 21.1 & 14.8 & 33.6 & 826.8 & 13.1 & 65.5 & 22.4 \\
\hline Standard Deviation & 25.5 & 10.0 & 8.7 & 5.1 & 20.2 & 121.8 & 7.3 & 9.1 & 13.2 \\
\hline Minimum-Maximum & $24-130$ & $20.1-63.1$ & $6.1-39.9$ & $6-27$ & $2.1-88.4$ & $513-1071$ & $3.2-37.3$ & 38.9-78.7 & $4.4-54.9$ \\
\hline
\end{tabular}

* Indicates countries with missing data

$\mathrm{n} / \mathrm{a}$ indicates a missing data value 
Table 3 Key nutrition Indicators and income status (poverty) from $\mathbf{4 0}$ countries in Sub-Saharan Africa

\begin{tabular}{|c|c|c|c|c|c|c|c|c|c|}
\hline Country & PPP & $\begin{array}{c}\text { HIV } \\
\text { prevalence } \\
(\%)\end{array}$ & $\begin{array}{c}\text { Energy } \\
\text { (cal/capita/ } \\
\text { day) }\end{array}$ & $\begin{array}{l}\text { Protein } \\
\text { (g/capita/ } \\
\text { day) }\end{array}$ & $\begin{array}{c}\text { Energy from } \\
\text { protein (\%) }\end{array}$ & $\begin{array}{c}\text { Fat } \\
\text { (g/capita/ } \\
\text { day) }\end{array}$ & $\begin{array}{l}\text { Energy } \\
\text { from fat } \\
(\%)\end{array}$ & $\begin{array}{l}\text { Carbohydrates } \\
\text { (g/capita/day) }\end{array}$ & $\begin{array}{c}\text { Energy from } \\
\text { carbohydrates } \\
(\%)\end{array}$ \\
\hline Angola & 54.3 & 2.0 & 1973 & 44 & 8.92 & 47 & 21.44 & 343.5 & 69.64 \\
\hline Benin & 47.3 & 1.2 & 2533 & 59.4 & 9.38 & 52.2 & 18.55 & 456.4 & 72.07 \\
\hline Burkina Faso & 56.5 & 1.2 & 2677 & 81.4 & 12.16 & 58.6 & 19.70 & 456 & 68.14 \\
\hline Burundi & 81.3 & 3.5 & 1685 & 45.6 & 10.82 & 13.4 & 7.16 & 345.5 & 82.02 \\
\hline Cameroon & 32.8 & 5.3 & 2269 & 57.4 & 10.12 & 42.6 & 16.90 & 414 & 72.98 \\
\hline Cape Verde & 20.6 & $\mathrm{n} / \mathrm{a}$ & 2572 & 69.5 & 10.81 & 76.8 & 26.87 & 400.7 & 62.32 \\
\hline $\begin{array}{l}\text { Central African } \\
\text { Republic (CAR) }\end{array}$ & 62.4 & 5.1 & 1986 & 46.1 & 9.28 & 64.9 & 29.41 & 304.4 & 61.31 \\
\hline Chad & 61.9 & 3.4 & 2056 & 61.5 & 11.96 & 49.1 & 21.49 & 342 & 66.54 \\
\hline Comoros & 46.1 & 0.1 & 1884 & 44.6 & 9.47 & 45.1 & 21.54 & 324.9 & 68.98 \\
\hline Congo Brazzaville & 54.1 & 3.5 & 2512 & 52.7 & 8.39 & 60.7 & 21.75 & 438.7 & 69.86 \\
\hline Cote d'Ivoire & 23.3 & 3.7 & 2528 & 49.9 & 7.90 & 47.2 & 16.80 & 513.3 & 81.22 \\
\hline $\begin{array}{c}\text { Democratic } \\
\text { Republic of Congo } \\
\text { (DRC) }\end{array}$ & 59.2 & 1.3 & 1605 & 24.4 & 6.08 & 24.3 & 13.63 & 322.2 & 80.30 \\
\hline Eritrea* & $\mathrm{n} / \mathrm{a}$ & 0.8 & 1605 & 47.3 & 11.79 & 25.4 & 14.24 & 296.8 & 73.97 \\
\hline Ethiopia & 39 & $\mathrm{n} / \mathrm{a}$ & 1980 & 56.7 & 11.45 & 21 & 9.55 & 391 & 78.99 \\
\hline Gabon & 4.8 & 5.3 & 2755 & 81.3 & 11.80 & 58.5 & 19.11 & 475.8 & 69.08 \\
\hline Gambia & 34.3 & 1.7 & 2385 & 55.7 & 9.34 & 68.4 & 25.81 & 386.6 & 64.84 \\
\hline Ghana & 30 & 1.8 & 2907 & 59.8 & 8.23 & 51.3 & 15.88 & 551.5 & 75.89 \\
\hline Guinea & 70.1 & 1.4 & 2568 & 54.4 & 8.47 & 62.9 & 22.04 & 446.1 & 69.49 \\
\hline Guinea-Bissau & 48.8 & 2.5 & 2306 & 44.3 & 7.68 & 50.9 & 19.87 & 417.7 & 72.45 \\
\hline Kenya & 19.7 & 6.3 & 2089 & 59.7 & 11.43 & 49.1 & 21.15 & 352.1 & 67.42 \\
\hline Lesotho & 43.4 & 23.6 & 2476 & 69.4 & 11.21 & 32.6 & 11.85 & 476.25 & 76.94 \\
\hline Liberia & 83.7 & 1.6 & 2204 & 36.5 & 6.62 & 57.1 & 23.32 & 386 & 70.05 \\
\hline Madagascar & 67.8 & 0.2 & 2160 & 49.9 & 9.24 & 31.9 & 13.29 & 418.3 & 77.46 \\
\hline Malawi & 73.9 & 11.2 & 2172 & 56.6 & 10.42 & 31.9 & 13.22 & 414.6 & 76.35 \\
\hline Mali & 51.5 & 1.0 & 2614 & 71.7 & 10.97 & 54.7 & 18.83 & 458.7 & 70.19 \\
\hline Mozambique & 74.7 & 11.4 & 2067 & 37.9 & 7.33 & 37.7 & 16.42 & 394 & 76.25 \\
\hline Namibia* & $\mathrm{n} / \mathrm{a}$ & 13.7 & 2383 & 67.9 & 11.40 & 55.7 & 21.04 & 402.5 & 67.56 \\
\hline Niger & 65.9 & 0.8 & 2376 & 80 & 13.47 & 46.5 & 17.61 & 409.4 & 68.92 \\
\hline Nigeria & 64.4 & 3.6 & 2741 & 63.5 & 9.27 & 66.5 & 21.84 & 472.1 & 68.89 \\
\hline Rwanda & 76.6 & 2.9 & 2085 & 49.5 & 9.50 & 20.1 & 8.68 & 426.5 & 81.82 \\
\hline $\begin{array}{l}\text { Sao Tome and } \\
\text { Principe* }^{*}\end{array}$ & $\mathrm{n} / \mathrm{a}$ & $\mathrm{n} / \mathrm{a}$ & 2684 & 60.5 & 9.02 & 74.9 & 25.12 & 442 & 65.87 \\
\hline Senegal & 33.5 & 0.8 & 2348 & 58.7 & 10.00 & 64.6 & 24.76 & 382.9 & 65.23 \\
\hline Sierra Leone & 53.4 & 1.6 & 2170 & 52.2 & 9.62 & 56 & 23.23 & 364.3 & 67.15 \\
\hline South Africa (RSA) & 26.2 & 17.9 & 2999 & 80.9 & 10.79 & 81.9 & 24.58 & 484.6 & 64.63 \\
\hline Swaziland & 62.9 & 25.9 & 2292 & 60.9 & 10.63 & 49.1 & 19.28 & 401.6 & 70.09 \\
\hline Tanzania & 88.5 & 5.8 & 2032 & 49.1 & 9.67 & 33.3 & 14.75 & 384 & 75.59 \\
\hline Togo & 38.7 & 3.2 & 2161 & 48.9 & 9.05 & 46.9 & 19.53 & 385.8 & 71.41 \\
\hline Uganda & 51.5 & 6.4 & 2211 & 48.7 & 8.81 & 42.6 & 17.34 & 408.2 & 73.85 \\
\hline Zambia & 64.3 & 13.6 & 1873 & 46.6 & 9.95 & 34.4 & 16.53 & 344.3 & 73.53 \\
\hline Zimbabwe* & $\mathrm{n} / \mathrm{a}$ & 15.1 & 2238 & 55.9 & 9.99 & 56.9 & 22.88 & 375.6 & 67.13 \\
\hline Mean & 51.8 & 5.69 & 2279 & 56.0 & 9.8 & 48.6 & 18.9 & 405.3 & 71.4 \\
\hline Standard Deviation & 20.0 & 6.49 & 334.3 & 12.6 & 1.6 & 16.1 & 5.0 & 56.7 & 5.3 \\
\hline Minimum & 4.8 & 0.1 & 1605 & 24.4 & 6.08 & 13.4 & 7.16 & 296.8 & 61.31 \\
\hline Maximum & 88.5 & 25.9 & 2999 & 81.4 & 13.47 & 81.9 & 29.41 & 551.5 & 82.02 \\
\hline
\end{tabular}

* Indicates countries with missing data.

$\mathrm{n} / \mathrm{a}$ indicates a missing data value. 


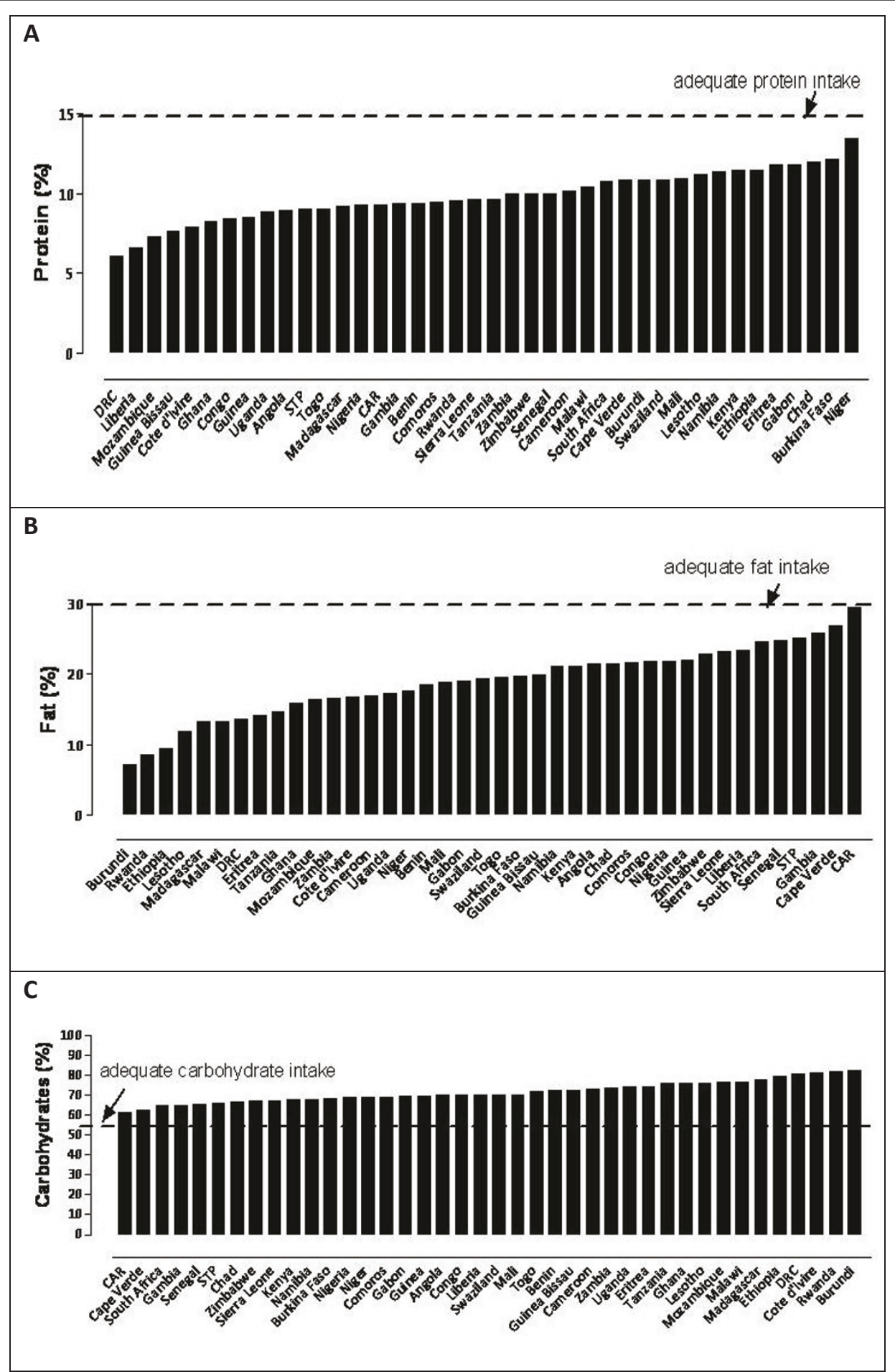

Figure 1 Protein, fat and carbohydrate intake as a percentage of DES in SSA. (A) protein as a percentage of DES, (B) fat as a percentage of DES, and (C) carbohydrates as a percentage of DES.

chose to breastfeed exclusively, despite the abundance of strategies directed at promoting exclusive breastfeeding in the continent. This prevalence is corroborated by those of WHO [19] that reported a finding of 30\% in SSA. Breast milk is always the best, especially in a continent that grapples with high levels of food insecurity, poverty and HIV/ AIDS infections. Breast milk provides just the right blend of proteins, fats, carbohydrates, minerals, and calories. 
Table 4 Correlations between independent variables (infant mortality rate and non-communicable disease mortality rate) and several predictor variables

\begin{tabular}{lcc}
\hline Independent Variable-Infant Mortality Rate & $\mathbf{r}^{* *}$ & P-Value \\
\hline Stunting & 0.41 & $0.01^{\dagger}$ \\
Underweight-for-Age* & 0.49 & $0.02^{\dagger}$ \\
Low birth weight & 0.31 & 0.06 \\
Exclusive breastfeeding & -0.33 & 0.05 \\
HIV prevalence* & -0.21 & 0.20 \\
PPP & 0.41 & $0.02^{\dagger}$ \\
Energy & -0.34 & $0.04^{\dagger}$ \\
Protein & -0.44 & $0.01^{\dagger}$ \\
Energy from protein & -0.35 & $0.04^{\dagger}$ \\
Fat & -0.14 & 0.53 \\
Energy from fat & 0.03 & 0.83 \\
Carbohydrates & -0.31 & 0.08 \\
Energy from carbohydrates & 0.08 & 0.60 \\
\hline
\end{tabular}

* Spearman's Rank Correlation (non-normal data)

${ }^{* *} \mathrm{r}$ is a measure of the linear relationship between IMR and the independent variables

${ }^{+}$Statistically significant at $p<0.05$

Furthermore, it contains antibodies, which help protect the baby from infections and diseases [20-22]. As such, the results of the current study have important implications for policy-makers in Africa, as it emphasizes the importance of exclusive breastfeeding in the prevention of infant mortality.

The current study also highlights the fact that many countries in SSA have at least a reasonable available intake of protein ( $>10 \%$ of total DES) and fat (> 20\% of total DES) [20]. The amount of protein consumed seems to be an important predictor for IMR in the current analysis. Indeed, results outlined in Figure 1a suggest that those individuals residing in DRC, Liberia and Guinea-Bissau consume the lowest amount of energy from protein, while at the same time having the highest levels of infant mortality (Table 2). Moreover, according to Earl and Borra [20], populations consuming 24-44 g of protein may not be getting enough essential amino acids. Amino acids are indeed crucial in the growth of infants; issues that have been stressed in child health for decades. Clearly, health workers in SSA need to prioritise strategies directed at emphasizing the importance of protein in the infants' diets as well as the promotion of exclusive breastfeeding for at least 6 months if the IMR is to be reduced.

The mean intake of $18.9 \pm 5 \%$ of the overall DES from fat in the current study poses concern. Thirteen to $24 \mathrm{~g}$ of fat is equivalent to at least 2.5 to 5 teaspoons of fat. These levels are very low when compared to the recommended daily allowance of at least $65 \mathrm{~g}$ for adults and children over 4 years $[20,21]$. As such, those individuals (especially children) consuming small amounts of fat may not be getting enough essential fatty acids to sustain their daily needs. It is therefore not surprising that countries at the lower extremes of total fat intake (Burundi with $13.4 \mathrm{~g}$ and DRC with $24.3 \mathrm{~g}$ ) also presented with high IMR of 102 and 126, respectively.

The fourth Millennium Development Goal (MDG) is to reduce child mortality. One of the indicators used to measure progress is the IMR [23], which is a commonly used indicator of a population's economic and social development [24]. Despite developing countries experiencing a decline in infant mortality during the last century, the results of the current study clearly show that the prevalence of undernutrition and infant mortality in SSA is still unacceptably high. These results are corroborated by other studies [25-27]. Moreover, according to Chopra and Darnton-Hill [28], the proportion and number of undernourished children in SSA has increased during the last 10 years.

Findings from this study indicate that the IMR in SSA ranges from as low as 24 to as high as 130 deaths per 1000 live births, while the percentage of stunted

Table 5 Results of multiple linear regression analysis using the outcome variable infant mortality rate

\begin{tabular}{|c|c|c|c|c|}
\hline \multicolumn{5}{|c|}{ Outcome: Infant Mortality Rate } \\
\hline & $\beta$ Coefficient & Standard Error & P-value & $\mathbf{9 5} \%$ confidence interval \\
\hline Underweight-for-age* & 1.03 & 0.41 & 0.020 & $0.17-1.89$ \\
\hline Protein** & -1.12 & 0.27 & 0.001 & $-1.67-(-0.56)$ \\
\hline Exclusively Breastfed* & -0.55 & -3.27 & 0.003 & $-0.90-(-0.21)$ \\
\hline Constant & 139.66 & 21.45 & 0.001 & $95.97-183.36$ \\
\hline \multicolumn{5}{|l|}{ Interpretation } \\
\hline Underweight-for-Age* & \multicolumn{4}{|c|}{$\begin{array}{l}\text { For every } 1 \% \text { increase in the number of children underweight-for-age, the infant mortality rate increases by } 1 \text { death per } 1000 \\
\text { infants }\end{array}$} \\
\hline Protein $^{\dagger}$ & \multicolumn{4}{|c|}{ For every $1 \mathrm{~g}$ increase in protein/capita/day, the infant mortality rate decreases by 1 death per 1000 infants } \\
\hline Exclusively Breastfed* & \multicolumn{4}{|c|}{$\begin{array}{l}\text { For every } 1 \% \text { increase in the number of infants that are exclusively breastfed for } 6 \text { months, the infant mortality rate } \\
\text { decreases by } 0.5 \text { deaths per } 1000 \text { infants }\end{array}$} \\
\hline
\end{tabular}

* Indicates measurement in percentage

${ }^{\dagger}$ Indicates measurement in grams/capita/day 


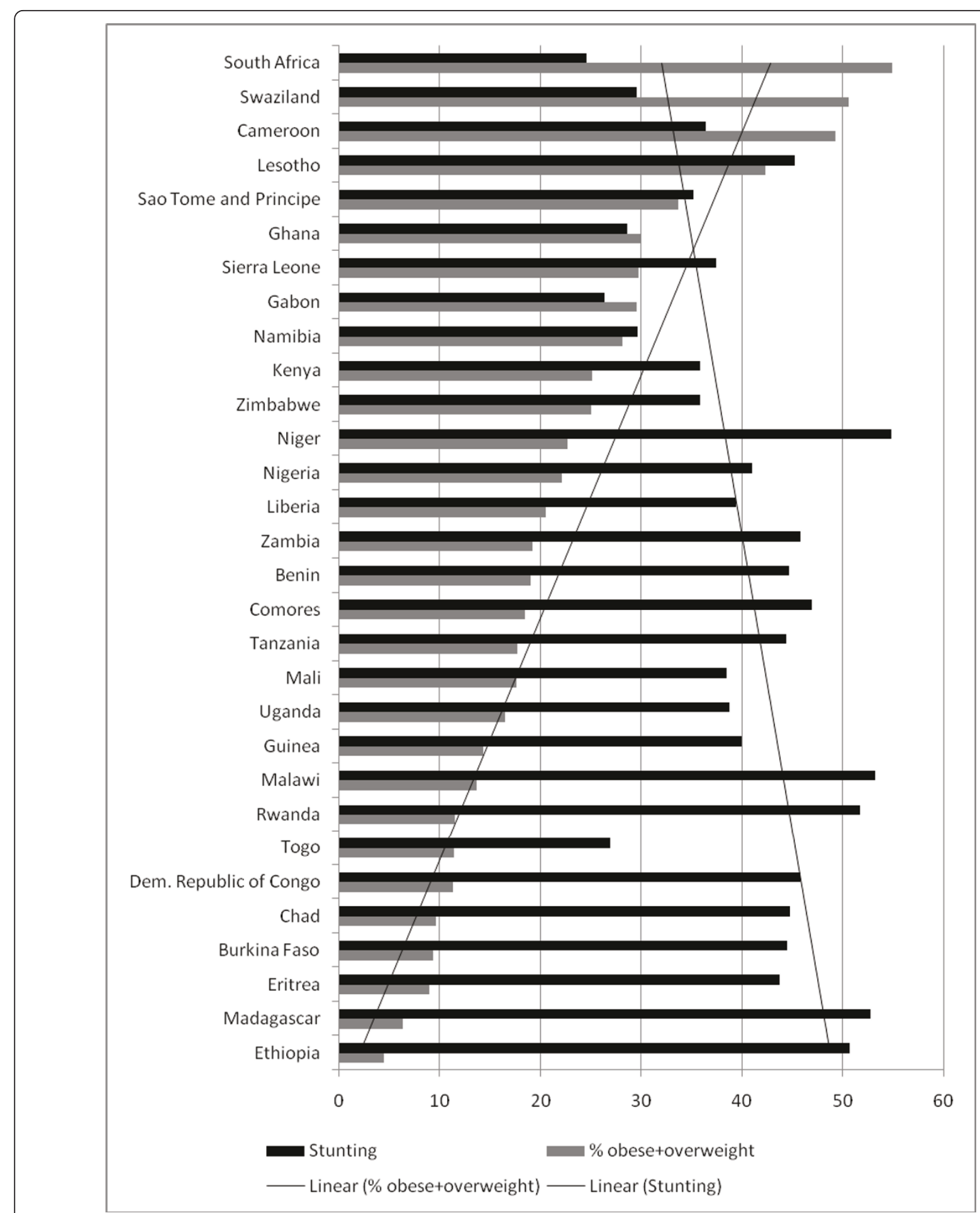

Figure 2 Relationship between Stunted children and overweight/obese women.

children range from $20 \%$ to $63 \%$. Countries with the highest nutrition transition scores were found to have relatively low levels of IMR, stunted children and underweight-for-age. Despite some countries having lower levels than others, the percentage of children that are stunted and underweight-for-age in SSA as a whole, is still disappointingly high. From these results we conclude that countries experiencing the nutrition-related 
Table 640 Sub-Saharan countries listed in descending order of Nutritional Transition Scores and the indicators that contribute to them

\begin{tabular}{|c|c|c|c|c|c|c|c|c|c|c|c|c|c|}
\hline \multirow[t]{2}{*}{ Country } & \multicolumn{2}{|c|}{ PPP } & \multicolumn{2}{|c|}{ Energy } & \multicolumn{2}{|c|}{$\%$ Energy from fat } & \multicolumn{2}{|c|}{ Over weight/obesity } & \multicolumn{2}{|c|}{ IMR } & \multicolumn{2}{|c|}{ Stunting } & \multirow[t]{2}{*}{ Score } \\
\hline & Low & High & High & Low & High & Low & High & Low & Low & High & Low & High & \\
\hline Angola & & & & $x$ & & & $\mathrm{n} / \mathrm{a}$ & $\mathrm{n} / \mathrm{a}$ & & $x$ & & $x$ & 0 \\
\hline Burundi & & $x$ & & $x$ & & $x$ & $\mathrm{n} / \mathrm{a}$ & $\mathrm{n} / \mathrm{a}$ & & $x$ & & $x$ & 0 \\
\hline Chad & & & & $x$ & & & & $x$ & & $x$ & & & 0 \\
\hline Comoros & & & & $x$ & & & & & & & & $x$ & 0 \\
\hline Congo Brazzaville & & & & & & & $\mathrm{n} / \mathrm{a}$ & $\mathrm{n} / \mathrm{a}$ & & & & & 0 \\
\hline Dem. Republic of Congo & & & & $x$ & & $x$ & & $x$ & & $x$ & & & 0 \\
\hline Ethiopia & & & & $x$ & & $x$ & & $x$ & & & & $x$ & 0 \\
\hline Madagascar & & $x$ & & & & $x$ & & $x$ & & & & $x$ & 0 \\
\hline Malawi & & $x$ & & & & $x$ & & & & & & $x$ & 0 \\
\hline Mozambique & & $x$ & & & & & $\mathrm{n} / \mathrm{a}$ & $\mathrm{n} / \mathrm{a}$ & & & & $x$ & 0 \\
\hline Niger & & $x$ & & & & & & & & & & $x$ & 0 \\
\hline Rwanda & & $x$ & & & & $x$ & & $x$ & & & & $x$ & 0 \\
\hline Tanzania & & $x$ & & $x$ & & $x$ & & & & & & & 0 \\
\hline Uganda & & & & & & & & & & & & & 0 \\
\hline Zambia & & & & $x$ & & & & & & & & & 0 \\
\hline Benin & & & $\checkmark$ & & & & & & & & & & 1 \\
\hline Burkina Faso & & & $\checkmark$ & & & & & $x$ & & & & & 1 \\
\hline Central African Republic & & & & $x$ & $\checkmark$ & & $n / a$ & $\mathrm{n} / \mathrm{a}$ & & $x$ & & & 1 \\
\hline Cote d'Ivoire & $\checkmark$ & & & & & & $\mathrm{n} / \mathrm{a}$ & $\mathrm{n} / \mathrm{a}$ & & & & & 1 \\
\hline Eritrea & $\mathrm{n} / \mathrm{a}$ & $\mathrm{n} / \mathrm{a}$ & & $x$ & & $x$ & & $x$ & $\checkmark$ & & & & 1 \\
\hline Guinea-Bissau & & & & & & & $\mathrm{n} / \mathrm{a}$ & $\mathrm{n} / \mathrm{a}$ & & $x$ & $\checkmark$ & & 1 \\
\hline Kenya & $\checkmark$ & & & & & & & & & & & & 1 \\
\hline Liberia & & $x$ & & & $\checkmark$ & & & & & $x$ & & & 1 \\
\hline Mali & & & $\checkmark$ & & & & & & & $x$ & & & 1 \\
\hline Nigeria & & & $\checkmark$ & & & & & & & $x$ & & & 1 \\
\hline Togo & & & & & & & & $x$ & & & $\checkmark$ & & 1 \\
\hline Cameroon & $\checkmark$ & & & & & & $\checkmark$ & & & & & & 2 \\
\hline Guinea & & $x$ & $\checkmark$ & & $\checkmark$ & & & & & & & & 2 \\
\hline Lesotho & & & & & & $x$ & $\checkmark$ & & $\checkmark$ & & & & 2 \\
\hline Namibia & $\mathrm{n} / \mathrm{a}$ & $\mathrm{n} / \mathrm{a}$ & & & & & & & $\checkmark$ & & $\checkmark$ & & 2 \\
\hline Sierra Leone & & & & & $\checkmark$ & & $\checkmark$ & & & $x$ & & & 2 \\
\hline Zimbabwe & $\mathrm{n} / \mathrm{a}$ & $\mathrm{n} / \mathrm{a}$ & & & $\checkmark$ & & & & $\checkmark$ & & & & 2 \\
\hline Gambia & $\checkmark$ & & & & $\checkmark$ & & $\mathrm{n} / \mathrm{a}$ & $\mathrm{n} / \mathrm{a}$ & & & $\checkmark$ & & 3 \\
\hline Sao Tome and Principe & $\mathrm{n} / \mathrm{a}$ & $\mathrm{n} / \mathrm{a}$ & $\checkmark$ & & $\checkmark$ & & $\checkmark$ & & & & & & 3 \\
\hline Swaziland & & & & & & & $\checkmark$ & & $\checkmark$ & & $\checkmark$ & & 3 \\
\hline Senegal & $\checkmark$ & & & & $\checkmark$ & & $\mathrm{n} / \mathrm{a}$ & $\mathrm{n} / \mathrm{a}$ & $\checkmark$ & & $\checkmark$ & & 4 \\
\hline Cape Verde & $\checkmark$ & & $\checkmark$ & & $\checkmark$ & & $\mathrm{n} / \mathrm{a}$ & $\mathrm{n} / \mathrm{a}$ & $\checkmark$ & & $\checkmark$ & & 5 \\
\hline Gabon & $\checkmark$ & & $\checkmark$ & & & & $\checkmark$ & & $\checkmark$ & & $\checkmark$ & & 5 \\
\hline Ghana & $\checkmark$ & & $\checkmark$ & & & $x$ & $\checkmark$ & & $\checkmark$ & & $\checkmark$ & & 5 \\
\hline South Africa & $\checkmark$ & & $\checkmark$ & & $\checkmark$ & & $\checkmark$ & & $\checkmark$ & & $\checkmark$ & & 6 \\
\hline
\end{tabular}

High refers to countries whose levels were in the top quartile Low refers to countries whose levels were in the bottom quartile n/a refers to countries with no available data

$\checkmark$ refers to levels included in the score

$\mathrm{X}$ refers to levels opposite to those included in the score

NCD phase of the transition, while experiencing high levels of obesity, are also experiencing a decline in rates for infant mortality and children that are stunted and underweight-for-age.
To speed up the reduction of infant and child mortality in SSA, countries need to allocate money to improving mother and child health care services and train health workers to detect and treat malnutrition related 
conditions as early as possible. Furthermore, improving the nutritional status of pregnant women will improve fetal growth which may lead to better health implications for many children [2].

Findings of the current study also show that RSA, Ghana, Gabon and Cape Verde had the highest nutrition transition scores. These countries with their relatively low levels of IMR and underweight, and relatively high levels of obesity/overweight, energy and fat intakes display classic signs of a population well established in the nutritionrelated NCD phase of the nutrition transition.

However, countries with a high prevalence of obesity/ overweight among women (Swaziland, Cameroon, Lesotho, and Sao Tome and Principe) were also found to have a moderate prevalence of children that are stunted (29-45\%), a low prevalence of children that are underweight-for-age (6-17\%), and nutrition transition scores of two and three. These findings confirm the prevalence of the dual burden household [9]. While the dual burden household appears to be prevalent throughout SSA, its prevalence is especially high in countries undergoing the receding famine stage of the nutrition transition. This is further supported by their average energy and fat intakes.

Findings show that more than half of the countries $(n=26)$ evaluated in this analysis had nutrition transition scores of zero and one. Most of them had a high prevalence of children that are stunted or underweightfor-age, small percentages of women that are overweight and obese, and low intakes of energy, protein, and fat. In addition, their IMR are moderate to high, and in most of these countries more than $50 \%$ of the population live on less than one dollar per day. These countries are still in the receding famine stage of the nutrition transition. This implies that within the next few years they can be expected to move into stages 3-5 with their typical pattern.

Since stunting and undernutrition during childhood is associated with obesity during adulthood [29], the co-morbidities related to obesity are bound to increase in countries still in the early stages of the transition. This will result in their moderate NCD mortality levels rising dramatically. As such, endorsing strategies directed at reducing food insecurity in these countries will directly reduce the prevalence of stunting and at the same time indirectly reduce the prevalence of chronic non-communicable diseases.

The scoring system developed and used in the analysis of this paper has attempted to identify each country's stage in the nutrition transition. This system has the potential to be applied to other developing countries, thereby identifying their stage in the transition and being able to predict areas of concern that are most in need of assistance.

\section{Conclusion}

Findings from this study show that countries in SSA are undergoing a nutrition transition. More than half of them are still in the early stages, while a few have reached a point where changes in dietary patterns are affecting health outcomes in a large portion of the population. Countries in the early stage of the transition are especially important, since the speed of transition is occurring more rapidly in lower- and middle-income countries. These countries are at risk of developing a high prevalence of obesity and NCD mortality more rapidly than has occurred in the West.

\section{Acknowledgements}

None

\section{Authors' contributions}

ZA: data collation, analysis and wrote the manuscript, and approved the final manuscript. NS: conceptualised paper, reviewed manuscript. Read and approved the final manuscript. ZM: involved in writing and reviewing manuscript. Read and approved final manuscript.

\section{Competing interests}

The authors declare that they have no competing interests.

Received: 30 June 2011 Accepted: 13 October 2011

Published: 13 October 2011

\section{References}

1. World Health Organisation: Nutrition in transition: globalization and its impact on nutrition patterns and diet-related diseases. 2003 [https://apps. who.int/nut/trans.htm].

2. Amuna P, Zotor F: Epidemiological and nutrition transition in developing countries: impact on human health and development. Proc Nutr SoC 2008, 67:82-90.

3. Omran AR: The epidemiologic transition: a theory of the epidemiology of population change. Milbank Mem Fund 1971, 49:509-38.

4. Popkin BM: An overview of the nutrition transition and its health implications: the Bellagio meeting. Public Health Nutr 2002, 5:93-103.

5. Popkin BM: Nutritional Patterns and Transitions. Population Devel Rev 1993, 19:138-57.

6. Popkin BM: The nutrition transition in low income countries: An emerging crisis. Nutr Rev 1994, 52:285-98.

7. Unwin N, Alberti G: Chronic non-communicable diseases. Ann Trop Med Parasitol 2006, 100:455-64.

8. Popkin BM: Part II. What is unique about the experience in lower- and middle-income less-industrialised countries compared with the veryhigh-income countries? Public Health Nutr 2002, 5(1A):205-14.

9. Doak CM, Adair LS, Bentley M, Monteiro C, Popkin BM: The dual burden household and the nutrition transition paradox. Int Journ Obes 2005, 29:129-31.

10. Maher $D$, Smeeth $L$, Sekajugo J: Health transition in Africa: practical policy proposals for primary care. Bull World Health Organ 2010, 88:943-48.

11. Bourne LT, Langenhoven ML, Steyn $K$, Jooste PL, Laubscher JA, Bourne DE: Nutritional status of 3-6 year-old African children in the Cape Peninsula. East Afr Med J 1994, 71:695-702.

12. Steyn K, Bourne L, Jooste P, Fourie JM, Rossouw K, Lombard C: Anthropometric profile of a black population of the Cape Peninsula in South Africa. East Afr Med J 1998, 75:35-40.

13. Garrett J, Ruel M: Stunted child-overweight mother pairs: an emerging policy concern? 2003 [http://pdf.usaid.gov/pdf_docs/PNACT013.pdf].

14. World Health Organisation: Global Health Observatory Database: Country Statistics. 2011 [http://apps.who.int/ghodata/?theme=country].

15. Demographic and Health Surveys: Country Reports. 2011 [http://www. measuredhs.com/countries/]. 
16. Food and Agriculture Organisation of the United States: FAOSTAT: Food Balance Sheets. 2011 [http://faostat.fao.org/site/368/default.aspx\#ancor].

17. Zere A, Mclntyre D: Inequities in under-five child malnutrition in South Africa. Int J Equity Health 2003, 2:7.

18. Unwin N, Setel P, Rashid S, Magusi F, Mbanya J, Kitange H, Hayes L, Edwards R, Aspray T, Alberti : Noncommunicable diseases in sub-Saharan Africa: where do they feature in the health research agenda? Bull World Health Organ 2001, 79(10):947-953.

19. World Health Organisation: Infant and young child feeding-Model Chapter for textbooks for medical students and allied health professionals. 2009 [http://www.waba.org.my/pdf/Infant-n-Young-Feeding. pdf].

20. Earl R, Borra ST: Guidelines for dietary planning. In Krause's food, nutrition, \& diet therapy. Edited by: Mahan LK, Escott-Stump S. WB Saunders Co; 2000:

21. Laquatra I: Nutrition weight management. In Krause's food, nutrition, \& diet therapy. Edited by: Mahan LK, Escott-Stump S. WB Saunders Co; 2000:.

22. UNICEF: Press Centre. 15 years after Innocenti Declaration, breastfeeding saving six million lives annually. 2006 [http://www.unicef.org/media/ media_30011.html].

23. Millennium Project: Goals, targets, indicators. 2006 [http://www. unmillenniumproject.org/goals/gti.htm].

24. Masuy-Stroobant G, Gourbin C: Infant health and mortality indicators: their accuracy for monitoring the socio-economic development in the Europe of 1994. Eur J Popul 1995, 11(1):63-84.

25. Harrtgen K, Misselhorn M: A multilevel approach to explain child mortality and undernutrition in South Asia and Sub-Saharan Africa. 2006 [http://econstor.eu/bitstream/10419/19847/1/Misselhorn.pdf].

26. Adetunji J, Bos ER: Levels and Trends in mortality in Sub-Saharan Africa: An Overview. In Disease and Mortality in Sub-Saharan Africa.. 2 edition. Edited by: Jamison DT, Feachem RG, Makgoba MW, et al. Washington (DC), World Bank; 2006:

27. Garenne M, Gakusi E: Health transitions in sub-Saharan Africa: overview of mortality trends in children under 5 years old (1950-2000). Bulletin of the World Health Organ 2005, 84(6):470-78.

28. Chopra M, Darnton-Hill I: Responding to the crisis in sub-Saharan Africa: the role of nutrition. Public Health Nutr 2006, 9(5):544-50.

29. Adair LS, Prentice AM: A critical evaluation of the fetal origins hypothesis and its implications for developing countries. J Nutr 2004, 134:191-193.

\section{Pre-publication history}

The pre-publication history for this paper can be accessed here:

http://www.biomedcentral.com/1471-2458/11/801/prepub

doi:10.1186/1471-2458-11-801

Cite this article as: Abrahams et al: Diet and mortality rates in Sub-

Saharan Africa: Stages in the nutrition transition. BMC Public Health 2011 11:801.

\section{Submit your next manuscript to BioMed Central and take full advantage of:}

- Convenient online submission

- Thorough peer review

- No space constraints or color figure charges

- Immediate publication on acceptance

- Inclusion in PubMed, CAS, Scopus and Google Scholar

- Research which is freely available for redistribution

Submit your manuscript at www.biomedcentral.com/submit 